\title{
THE BATTLE OF LEPANTO: A CULTURAL IMAGE FROM HISTORY TO SPANISH LITERATURE
}

\author{
Oana Andreia Sambrian \\ Academia Rumana, Instituto de Ciencias Sociales y Humanidades, Craiova, Rumanía \\ oana.sambrian@gmail.com
}

\begin{abstract}
The battle of Lepanto represents one of the most successful literary and artistic recreations of a military event, as its echo travelled fast, reaching the New World shortly. Its image was illustrated in Spain throughout the 16 th and 17th centuries in relaciones de sucesos, chronicles, poems, plays and paintings. Our article focuses on all these different types of information, in an attempt to show the complexity of the phenomenon of the battle of Lepanto. The information provided focuses solely on the elements of novelty, insisting very little on what has already been detailed by the previous historiography. Our corpus includes paintings by Titian and works by Fernando de Herrera, Luis Vélez de Guevara, Lope de Vega, González de Eslava etc.
\end{abstract}

KEYWORDS: Lepanto, image, theater, Lope de Vega, cultural propaganda.

\section{LA BATALLA DE LEPANTO: UNA IMAGEN CULTURAL DESDE LA HISTORIA HASTA LA LITERATURA ESPAÑOLA}

RESUMEN: La batalla de Lepanto representa uno de los mayores éxitos artísticoliterarios de la recreación de un evento militar, ya que su eco viajó muy de prisa, alcanzando muy rápidamente el Nuevo Mundo. Su imagen en la España de los siglos XVI-XVII se dio en relaciones de sucesos, crónicas, poemas, obras de teatro y cuadros. Nuestro artículo se centra en los diferentes tipos de información, en un intento de ilustrar la complejidad del fenómeno de la batalla de Lepanto. La información que hemos proporcionado solo hace hincapié en aquellos elementos de novedad, sin insistir en lo que la historiografia anterior ya se ha encargado de detallar, remitiendo por lo tanto a dichas fuentes. Nuestro corpus incluye obras de Tiziano, Fernando de Herrera, Luis Vélez de Guevara, Lope de Vega, González de Eslava, etc.

PALABRAS CLAVE: Lepanto, imagen, teatro, Lope de Vega, propaganda cultural.

Copyright (C) 2021, Los autores. Este artículo está bajo una licencia de Creative Commons Reconocimiento 4.0 Internacional (CC BY) (http://creativecommons.org/licenses/by/4.0/) 


\title{
LA BATAILLE DE LEPANTE: UNE IMAGE CULTURELLE DEPUIS L'HISTOIRE JUSQU'A LA LITTERATURE ESPAGNOLE
}

\author{
RÉSUMÉ : La bataille de Lépante représente l'un des plus grands succès \\ artistiques et littéraires dans la reconstitution d'un événement militaire, car \\ son écho a voyagé très rapidement jusq'au Nouveau Monde. Son image dans \\ l'Espagne des XVIème-XVIIème siècles a été illustrée à travers des canards, des \\ chroniques, des poèmes, des pièces de théâtre et des peintures. Notre article se \\ concentre sur les différents types d'informations, dans une tentative d'illustrer la \\ complexité du phénomène de la bataille de Lépante. Les informations que nous \\ avons fournies ne font que souligner ces éléments de nouveauté, sans insister sur \\ ce que l'historiographie précédente s'était déjà chargée de détailler. Notre corpus \\ comprend des euvres de Tiziano, Fernando de Herrera, Luis Vélez de Guevara, \\ Lope de Vega, González de Eslava, etc.
}

MOTS CLÉS : Lepanto, image, théatre, Lope de Vega, propagande culturelle.

Recibido: 20/03/2021. Aceptado: 18/05/2021

For Fernand Braudel, at the end of the $16^{\text {th }}$ century, the balance of forces in the Mediterranean Sea had changed a lot, due to the decadence of the mercantile Italian republics and the transfer of the economical focus from South to North, which made the Mediterranean lose its status of neuralgic center of the Occidental countries. Until that moment, according to Ricardo Cerzo Martínez, during the first half of the $16^{\text {th }}$ century, the Christian empire of Charles V and the Ottoman Empire of Suleiman the Magnificent had polarised irremediably antagonistic forces (1988: 189-231). The latter had conquered Buda, directly menacing Vienna and the Italian republics. The Ottomans based their power on important human resources, as well as on the alliance with the pirate republics of the Berbers, while efficiently taking advantage of the technological advances. Although we should not reduce the European political and strategical approach to a permanent effort to counteract the hegemony of the Sultan, we should nonetheless consider that the fear of Turks was a constancy in the mentality of Occidental Mediterraneans. At the beginning of the $17^{\text {th }}$ century, for example, the expression "que baja el turco, que baja el turco" had become very common and was part of the popular culture, which reinforces the persistence of fear. This is why a victory against the all-time enemy, although many times insignificant from the military point of view, was highly important in order to nourish the expectations of the collective memory. 
Augustin Redondo refers to the battle of Lepanto, the naval battle par excellence, as "esa insigne victoria que les daba la impresión de que ya podían triunfar de los turcos (...) y desechar el miedo que les inspiraban" (Redondo 2003: 236).

In actual fact, significant historical events, such as Lepanto, undertook an interesting trajectory since they were first mentioned by a historical source until becoming a cultural product, due to their reception by popular literature, which had a huge impact on the collective memory. In our article, we are going to make use of the different sources of information about Lepanto, both literary and artistic, in order to recreate the path the information followed since the historical event took place until it became an echo or a collective memory through its projection in art and literature.

As Cristóbal Mosquera de Figuera pointed out when congratulating Ercilla for publishing the historical actions of the Spanish people in verses, Poetry was more universal than History, which reinforces the idea that literature and history went hand in hand to complete the circuit of information.

Therefore, Spanish people used literature in an attempt to exonerate their fear of the Turks, who they represented in works that can be divided into two currents: Turkophobia and Turkofilia.

Ricardo García Cárcel identifies three different stages of Turkophobia during the Spanish Golden Age, that can subsequently be used in order to understand the literary phenomenon of Lepanto: before the Moorish rebellion of 1568, as this implied a potential Muslim connection on both sides of the Mediterranean; the period 1568-1609, before the expulsion of the Moors; after the year 1609 (1994: 19). The debate around the concept of Turkofilia is not exactly accurate according to García Cárcel for several reasons. But first of all, we are going to illustrate the classical conceptions about the friendly image of the Moors in the Golden Age Spanish literature. For Menéndez y Pelayo, the pro Moorish literature is an example of the generous idealization that the victorious people had about their ancient dominators. Secondly, we have the psychological interpretation of Goytisolo, for whom, this type of literature represents the testimony of the bad historical conscience, which aimed at evading its own responsibilities through a sweeten literature (García Cárcel 1994: 18). More recently, García Cárcel insists on nuancing some aspects related to Turkofilia literature. To begin with, he explains there are still very few examples to support this assertion, such as the Abencerraje, Guerra civil de Granada by Pérez de Hita, or Verdadera historia 
by Miguel de Luna. In García Cárcel's viewpoint, the concept of Turkofilia is misinterpreted, as the promotors of the Abencerraje or of the work of Pérez de Hita have nothing whatsoever in common with the feeling of a true Moor, such as Miguel de Luna. That is why, many of the opponents of the Moorish expulsion were not Turkofils, but they just supported different strategies than the ones which were officially accepted. Apart from that, we cannot possibly ignore history. And although it is true that literature does not have to be completely loyal to it, we cannot judge altogether the Abencerraje, written before the Moorish rebellion, and the work of Miguel de Luna, written just before the expulsion (García Cárcel 1994: 19).

The works we are going to illustrate in our article focus on the same topic, the naval battle of Lepanto (1571), which corresponds historically to the second period of events alleged by García Cárcel, a time characterized by the harshness in the revaluation of the Turks. It is indeed a time of increasing tensions, determined by the politization of the Moorish problem, as well as by the radicalization of the experience of captivity or the pirates' relentless pursue. Following the increasing menace of the Ottoman Empire, the Holy League was created, integrated by Spain, the Holy See and La Serenissima (Venice). Subsequently, the agreement between la Serenissima and the Sublime Porte ended the Catholic coalition. After the Ottomans recovered Tunis, the two sides reached a relative truce until 1581 and subsequently, the hostilities reappeared following the year 1595 and the Ottoman campaign on the Danube. But the Mediterranean, although a constant issue, did not represent the only concern of the Spanish kings, as they also had to face turbulences in the Netherlands. Whenever they did not have any additional problem, as registered between 1609 and 1621 when the hostilities with the Dutch were suspended, the Spanish kings turned their eyes towards the Mediterranean.

The battle of Lepanto has been interpreted in many different ways throughout time and historiography. For its contemporaries, it was "suceso digno de ser celebrado en todas las edades" (Herrera 1572: A3r) or "inmortal vitoria alcanzada / contra bárbara gente" (Lofrasso 1571: 3r)1. For Miguel de Cervantes, Lepanto represented "la más memorable ocasión que vieron los pasados siglos ni esperan ver los venideros" (Cervantes 2000: 51). The author of Don Quixotte, also recalls

1. A detailed analysis of Lofrasso's work can be found in the recent study of Marta Galiñanes Gallén, "La batalla de Lepanto desde un pequeño reino del Imperio: El verdadero discurso de la gloriosa victoria que N.S. Dios ha dado al Serenissimo señor Don Juan de Austria contra la armada del Turco en los mares de Lepanto" (Ciappelli, Nider 2017: 163-175). 
his own experience during the battle of Lepanto in his Epistola a Mateo Vázquez, where he claims:

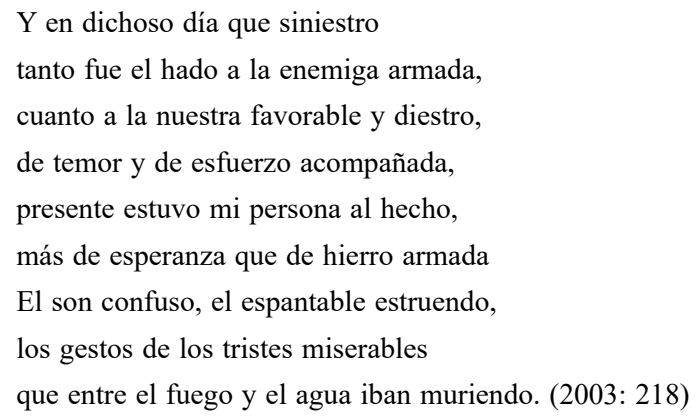

The Spanish king received the news of the victory from the Venetian ambassador in Madrid. Several poems celebrated the victory of the Christian army, don Juan or the Pope: Juan Rufo, a soldier who took part in the battle from the galley of don Juan de Austria and published La Austriada in 1584, Francisco Pedrosa, who wrote a long poem about Lepanto in Latin, La Araucana by Alonso de Ercilla, where a wizard lifts the narrator on top of the world and from there he can see the battle of Lepanto, or Góngora who depicted the fight in the romance Desbaratados los cuernos.

Many centuries later, the historians' opinion about Lepanto started oscillating. Braudel, followed by Hess (1982: 90-114) did not value the results of the Catholic victory of 1571 , whereas recently the potential results of the battle are being revaluated (Hassiotis 2001: 37-46) or focus on the propagandistic image of the event (Rivero 2008). Another interesting point of view is expressed by David and Enrique García Hernán in Lepanto, el día después, as the question that arises the day after the huge naval victory against the infidels seems to be: now what? For the two Spanish historians, the result of Lepanto had to face other greater dilemmas. On the one hand, the king had to choose his next battle field: Tunis or Levant? On the other, there had to be taken into consideration the impressive necessities that derived from the support and reorganization of another sea expedition: the general resources, the accommodation, the supplies, the information service, the ships etc. Therefore, this difficulty was going to result in a parallel battle: a logistic one (García Hernán 1999).

In another one of his articles, Consecuencias politico-culturales de la batalla de Lepanto, David García Hernán is of the opinion that "without a shadow of a 
doubt, Lepanto represents a singular case in the History of Literature, given the quantitative impact it supposed" (2011: 470).

And the impact was indeed huge, if, above all, we take into consideration the diversity of sources that recorded the event and which can be divided into three categories: informative, celebrative and both. One of these types of sources are the newsletters, known in Spanish as relaciones de sucesos, or proto newspapers. This type of source, published mainly in Seville, was very much spread in the second half of the $16^{\text {th }}$ century and came to light in a background of military chronicles and war stories; a good example in this sense is Francisco López de Gomara's Guerras del mar del Emperador Carlos V (1552), which focuses on the battle for the supremacy of the sea from 1500 to 1556 . One of the important works that retrieves 16 of the relevant newsletters about Lepanto belongs to Mercedes Agulló y Cobo: "Relaciones de sucesos I: años 1477-1619” (1966). The number of triumphant newsletters about the victories of the Christians against the Turks was huge. Seville only published 25 of them between 1594-1606 in the printing press of Rodrigo de Cabrera (Redondo 2001: 162-163). I would also want to point out that many of these "relaciones" start with the word "verdadera", regardless of the degree of subjectivity of the paper or they mention that the information came from letters received directly from the battle field, in order to give the newsletter more accuracy. Despite that, the historian has to read many times between the lines, as some newsletters come as a result of a subjective, propagandistic approach.

One relevant example in this sense could be Verdadera relación conforme a muchas cartas que han venido a esta ciudad de la feliz victoria que tuvo don Antonio de Aragón, hermano del Duque de Gandía y sobrino del Duque de Lerma contra las galeras de Chipre y Rodas en la isla de Sio, a mediados de agosto de este año 13. Con otras presas que han tenido las galeras de Venecia, Florencia y los navios del Conde Mauricio (1613: 477-478). According to its relator, the battle of Lepanto was "uno de los mayores golpes que ha recibido el Turco (...) y una de las más reñidas batallas que han sucedido en el Mediterráneo".

A good example of newsletter that delivers information in a more objective way is La copia y traslado de una carta venida a la corte de su magestad a los 23 de noviembre en que se cuenta muy en particular la victoria avida de los turcos en la batalla naval (1571). The system of correspondence which tends to objectify the truth is one of the most common features of this genre. Another "relación" I would like to point out is Fernando de Herrera's Relación de la guerra de Chipre y relato de la guerra naval de Lepanto. The author declares 
himself a truth seeker as no other before him, using multiple types of sources, ranging from the oral to the written ones: "Ninguno tuvo más copia de relaciones y ninguno inquirió la averiguación de la verdad con más deseo".

All newsletters share a common scheme: the titles are grandiloquent, announcing admirable deeds and calling the enemy "Mahoma's sect". Juan de Austria is presented as a direct descendent of Charles V, being compared to the Greek god of war: "Su Majestad muy bien ha elegido / a su propio hermano, nuevo Marte" (Lofrasso 1571: 53-54)2.

The images on the title page focus on the coat of arms of the Monarchy, which makes the information official (Civil 2003: 110). Many newsletters about Lepanto use the same engraving, that reflects the boarding of a Ottoman galley by a Christian ship. In the middle of this composition, we can perceive a character in his armor, holding the sword in one hand and what appears to be the head of the enemy in the other. The newsletter ends with a plea of the glory of God or of the Virgin Mary (Civil 2003: 110).

The artistic representations of battles were meant to have a strong impact on the viewer, as well as behold a propagandistic message. In the case of Lepanto, as Manuel Fernández Álvarez recalls, it is impossible not to think of Charles V (Fernández Álvarez 2004: 466) and his original plan of a Holly League, that also included the Vatican and Venice and another important contributor: Charles's brother, Ferdinand of Habsburg. It is actually in memory of his father that Philip II hires Titian to paint his victorious portrait after Lepanto, just as his father had done in the past after Muhlberg. In 1571, Titian was 95 years old, but could still paint, so Philip sends him a drawing manifesting his will of what the celebration of Lepanto needed to include. In 1573, at the age of 97 and without the possibility of leaving Venice, Titian accepts Philip's commission which he is going to finish two years later, at 99, one year before his death.

In Philip II offering the infant Fernando to victory, we can appreciate the complexity of the message that Philip wanted to spread. To begin with, on the 5th of December 1571, Philip had become a father to Ferdinand, the first son with his fourth wife, Anne of Austria, which had made him very happy, especially after the tragic death of don Carlos. Following the appearence of his new born son, Philip wanted both victories, - the one in the military and the one in the sentimental field - to be reflected by Titian. As a result, the lema "Maiora tibi",

2. For further information about the image of the Habsburg kings as Mars, see the article, "Imágenes del triunfo de Carlos Quinto en el teatro del Siglo de Oro" (Sambrian 2017: 11-26). 
engraved on the victory palm that the angel is handing Philip and his son, is a reflection of the bright future that the king awaits for his son to have. The Spanish king is represented, as had been his father before him, in his armour and wearing a sword, whereas in the left corner of the painting we behold the supreme image of defeat: a Turkish soldier lying with his hands tied behind his back, with his most distinctive symbol, the turban, on the ground. Of course, the difference with Charles's portrait is huge. In the case of Charles V on horseback from the Prado Museum, the emperor appears alone at the center of the painting as the only, true crusader, with the battle field showing behind him. The elements of historical accuracy are given by the armour and harness the Italian artist had depicted, both being kept at the Royal Armoury in Madrid. One of the biggest differences in terms of accuracy between the portraits of Charles and Philip, was the fact that in 1548 when he painted Charles's victory against the protestants at Muhlberg, Titian was 72 years old, so he traveled to Augsburg to paint the emperor in person. In the case of Philip, Titian recieved a portrait of the Spanish king made by Sánchez Coello. In any case, both paintings hold an element of continuity, as Philip intentionally used the author of his father's famous portrait in order to spread the word that Charles's dream, his mission against the Ottoman infidels, had finally been completed.

Apart from the types of sources I have so far presented, I want to illustrate one more, which I have always considered extremely important when it comes to demonstrating the echo of groundbreaking historical events: theater. According to García Hernán (2006: 152-153), the functions of theater were very wide due to the power of representation, including the staging of ideologies, the image or heroism as supreme virtue, the demonisation of the enemy etc.

The debate about the kind of plays we can include into the vast, yet still undefined category of historical theater has been at steak in recent years. In his article from 2015, "La fuerza de las historias representada. Reflexiones sobre el drama histórico: los reyes de la historia de España en los teatros del Siglo de Oro" (2015: 57-58), Juan Matas Caballero maintained that we still need to identify those common features that allow the identification of historical plays. In a conference from November 2018 presented at the Spanish National Library, "Si hablare el rey, imite cuanto pueda / la gravedad real»: de nuevo sobre la imagen de los Reyes católicos en el teatro de Lope de Vega", I have retaken the topic exposed by Matas Caballero, concluding that the best factor to take into consideration when referring to historical plays is not the distance in time from the event that has taken place, but corroborating that both action and characters 
create a historical atmosphere, as well as the proportion of historical elements in the play.

For the current article I have selected the information present in plays we don't often take so much into consideration when speaking about Lepanto (except for La Santa Liga): Coloquio Doze, De la batalla naval que el serenísimo Príncipe don Juan de Austria tuvo con el Turco (probably written for the celebration of the Corpus from 1572) by Fernán González de Eslava, La Santa Liga (1598-1603) by Lope de Vega, El hijo del águila (around 1627) and El águila del agua y batalla naval de Lepanto (1642) both by Luis Vélez de Guevara. All these plays correspond to the so called second and third stages of Moorish literature aforementioned.

Coloquio Doze by González de Eslava is not a very well known play about Lepanto, although its study reveils interesting information about the way this historical moment was represented in the New World (Eslava's Coloquios were published in 1610). According to the Actas del Cabildo from Ciudad de México, a big civilian representation of the battle of Lepanto was held in the main square, confronting the Christian and the Turkish fleet (Mariscal Hay 2009: 374). Eslava's play includes seven characters: Life, Death, a simple man, a soldier of Fame, a Turkish man, an angel and a dead soldier. The description of the battle is made through the narration of one of the characters, a technique we are going to insist on in the analysis of the following play. Coloquio Doze enhances a series of patterns common to all plays that focus on Lepanto: the fame of Don Juan de Austria as rightful heir of his father, emperor Charles V, the triumph of the Christian army as a result of the support of the true God:

\author{
Debajo de un palio de gloria \\ puso al Príncipe excelente \\ Don Juan de Austria y su vitoria \\ consagrada eternamente \\ al Templo de la Memoria.
}

Si querías heredero,

ya ves tu gozo cumplido. (Mariscal 2009: 377)

Detailed information about the battle of Lepanto is given by the Soldier of the house of Fame in reply to the Simple man who declares knowing nothing about the battle. The Soldier was a direct participant to the fight and claimed that only an ignorant could know nothing about this great achievement: 


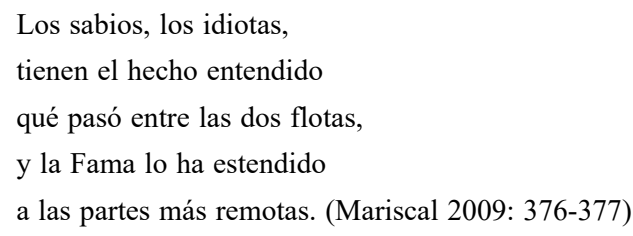

The play in itself holds nothing special in terms of information or dramatic execution, but it is appealing as it shows an early source of information, very close to the moment the battle took place. At the same time, it also demonstrates how fast information circulated in the Spanish empire and how efficient the Spanish propagandistic machinery was, diseminating the information until the New World, in a time when the protestants were becoming each time more menacing for the Catholics.

As for the next play, I am not going to insist a lot on its purpose because $L a$ Santa Liga is the typical example we use in theater when we wish to illustrate the dramatic echo of the battle of Lepanto. A historical approach to this play can be found in "In hoc signo vinces: representación y escenificación de las cruzadas en el teatro de Lope de Vega" (Sambrian 2011: 149-166). That aside, all the important historians and philologists that have spoken about Lepanto have analysed the propagandistic message of the play, therefore it is not my intention to retake that issue, but to illustrate how the battle was shown to the audience.

In Lope's La Santa Liga I have identified the typical structure of the plays about Moors and Christians, which normally include a main historical action, followed by a secondary action focused, generally, on a lovestory. The topic of this kind of play also includes the recreation of the battle with theatrical techniques, such as music, noise and sounds:

- the conflict: the main action - the battle of Lepanto, the recreation of the Moorish world in Spain; the secondary action: the love between sultan Selim and his wife, Rosa Solimana, as well as the affairs between Mustafa and Constancia, and Selim and Fatima;

- the preparation for the battle: the ghost of Selim's father appears, convincing his son to start a big anti-Christian campaign. Mustafa goes to Venice to give an ultimatum to the Senate. The representatives of Spain and the Vatican agree to create the Holy League in Rome. Don Juan de Austria and the Christians receive the news that the Ottomans have conquered Famagusta. 
- the fight: the allegorical characters Venice, Rome and Spain narrate the events of the battle of Lepanto, a very common technique when it is difficult to stage the fight.

- the end: the Christian victory. Ali's death. Don Juan is received as a hero in Messina.

As to the theatrical techniques used to recreate the battle, when it came to staging the armies involved in the fight, it was almost impossible to get enough actors to form a regiment on stage because of the narrow space. Therefore, there were only two options used to represent the mob: either through the manipulation of the visual and auditive space, either by the manipulation of the characters (Kirschner 1998: 35). The manipulation of the characters is achieved through the technique Teresa Kirschner refers to as "la masa actor en escena": "Vayanse y salgan los esclavos que puedan". The sound had a descriptive and deictic function, following the entry of a group of actors: "Vanse y salgan cajas $y$ bandera y Turcos".

The sounds are also used in order to fake the fight behind the curtains, so without actually representing it, something achieved through stage directions: "Vanse y salen después de fingir una guerra adentro tres turcos $(\ldots)^{\prime \prime}$

Narration and dialogues are other techniques employed in order not to have to actually represent the battle on stage. In La Santa Liga, Suriano and Juan speak about the military forces of the Spaniards:

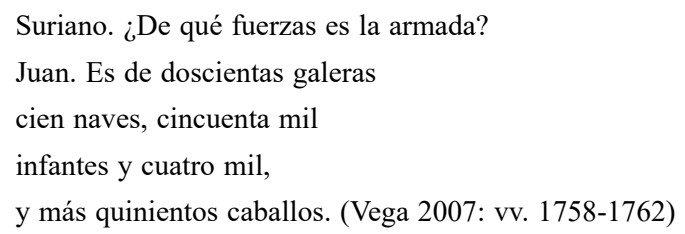

According to García Hernán, the historical data presented by Lope corresponds quite well to the information given by historians (García Hernán 2011: 490).

As mentioned above, La Santa Liga includes the presence of three allegorical characters, Venice, Rome and Spain, that use long descriptive paragraphs to illustrate the naval battle: 
Venecia.

Cierra la cortina y mira

cómo ya la primera vela

de las otras se retira

y a dar el aviso vuela.

Oye la naval batalla.

Las islas Escorzolares

va dejando nuestra armada

y por la boca del golfo

de Lepanto alegre pasa (...)

Ya don Juan puesto en la popa

un crucifijo levanta (...) (Lope 2007: vv. 2588-2605)

The next stage direction, "Disparen dentro", alerts the public that the battle has started. Certain words used in the dramatic discourse, such as "look" or "hear", invite the spectators to make use of their senses and imagination in order to recreate the battle.

Roma.

Qué bien parece la armada, don Juan la batalla guía (...) (Lope 2007: vv. 2621-2622)

The topic of portraying real historical characters on stage is so attractive for the reader-spectator that the authors agree to expose in their texts thorough lists of characters that interest the audience, given the higher approach between the topic of the plays and their own concerns. The concern of the audience was such, that during one of the representations of a comedy about the war in Flanders, a spectator interrupted the play and came on stage asking to change the lines of an "alférez" (sub-lieutenant), as it did not correspond to reality (García Hernán 2011: 490)

Moving forward to the plays of Vélez de Guevara, El hijo del águila and El águila del agua, both have been many times confused given the similarity in their titles. About the different attributions of the plays, see the complete study of Javier González Martínez, "La educación del poder a través del teatro: $E l$ hijo del águila de Luis Vélez de Guevara" (2012: 37-53) and the contribution 
of Germán Vega to the Philological Dictionary of Spanish Literature (2009: 580-612)

El hijo del águila focuses on Charles I of Spain and his fight against the Ottoman Empire, as well as on the presence at court of his bastard son, Juan. The play is scattered with information about the Moors, but the most interesting part can be found in the third act, where two of the characters, Juan and Jergón, imagine a naval battle that resembles Lepanto:

\author{
Juan. Jergón, mira atentamente \\ el sitio desta campaña \\ que notable espacio ocupa \\ tan estendida y tan llana: \\ yo considero que el mar \\ es desta suerte. \\ Ya sobre su espejo de plata \\ parece, Jergón, que miro \\ una poderosa armada \\ de galeras, donde soy \\ general, y que me llaman \\ príncipe del mar y alteza. \\ (Vélez, s.a.: 14r)
}

One of the main sources of inspiration for Vélez's play was Vander Hammen's biography, Juan de Austria (1627), where Vélez must have found the episode of Juan's flight from the custody of Luis Quijada. Also, the dramatist was inspired by Hammen in the depiction of the imaginery battle of Lepanto (Vander Hammen 1627: 174-182, Vélez, s.a.: h. 14r). Another source of inspiration was Prudencio de Sandoval's Historia de la vida y hechos del Emperador Carlos $V$.

In El águila del agua, although Don Juan still plays an important part (the author mentions that the Pope had chosen him as general of the Christian troops), the mob is presented in detail alongside its crucial role in the progress of the battle, which makes it a curious play. According to Ruano de la Haza and John Allen, there are several elements that make us think that the play was created in order to be represented at the royal court: the topic, the elevated number of characters, the musical environment (1994: 343-344). The originality of this play lies in the fact that not only noblemen are capable of great, heroic actions, but 
also the mob, something that gives a lot of realism and credibility to the play. It would be highly impossible to believe that noblemen could have alone won all the battles that have been fought throughout history:

\author{
Escamilla. Soy hombre de bien y halléme \\ en la ocasión que me pesa \\ ver ventajas y ayudé; \\ sin conocer a su Alteza \\ que con don Lope venía (...) (González 2007: 225)
}

All in all, Lepanto was a moment that should be understood, not only in its historical background, but also as a cultural product, that could be very easily commercialised. Because people were interested, regardless of their social status. As the soldier from Doze coloquios had declared, only an idiot would know nothing of the great victory of Christianity against the long-time successful Ottoman Empire. And although this victory did not have a great impact on the forecoming military hostilities, it did have huge consequences on the moral side. For all those people, bad or good, rich or poor, who were afraid of the Moors, it is very likely a myth died that day: the myth of the invincibility of the worst enemy of Charles V, the enemy that the emperor had struggled so much to chase away from Europe.

This is the only reasonable explanation we can find in order to justify the heartfelt cultural success of Lepanto. Because, in the very end, the true expression of a successful military action lies in its cultural echo: as long as it keeps people interested, it is always going to live on in their memory.

\title{
References
}

AGULLÓ Y COBO, M. (1966). "Relaciones de sucesos I: años 1477-1619". Cuadernos Bibliográficos 20: 1-85.

CERZO MARTÍNEZ, R. (1988). Las armadas de Felipe II. Madrid, San Martín. CERVANTES, M. (2003). "Epístola a Mateo Vázquez". Cervantes: Bulletin of the Cervantes Society of America 23.1: 215-222.

CERVANTES, M. (2000). Novelas ejemplares, tomo I. Madrid, Cátedra.

CIAPPELLI, G. y NIDER, V. (2017). La invención de las noticias. Las relaciones de sucesos entre la literatura y la información (siglos XVI-XVIII). Trento, Università degli Studi di Trento. 
CIVIL, P. (2003). "Las relaciones de batallas navales en el Mediterráneo (siglos XVI-XVII): estrategias narrativas". En Paba, T., Andrés, G. (eds.), Encuentro de civilizaciones (1500-1750). Informar, narrar, celebrar. Alcalá, Servicio de Publicaciones de la Universidad de Alcalá, pp. 105-117.

FERNÁNDEZ ÁLVAREZ, M. (2004). Felipe II y su tiempo. [Vigésima edición]. Madrid, Espasa Calpe.

GARCÍA CÁRCEL, R. (1994). "La psicosis del turco en la España del Siglo de Oro". En Pedraza, F., González Cañal, R. (eds.), Los imperios orientales en el teatro del Siglo de Oro. Almagro, pp. 15-28.

GARCÍA HERNÁN, D. y GARCÍA HERNÁN, E. (1999). Lepanto, el día después. Madrid, Actas.

GARCÍA HERNÁN, D. (2006). La cultura de la guerra y el teatro del Siglo de Oro. Madrid, Sílex.

GARCÍA HERNÁN, D. (2011). "Consecuencias político-culturales de la batalla de Lepanto". Mediterránea. Ricerche storiche 23: 467-500.

GONZÁLEZ DE ESLAVA, F. (1998). Fernán González de Eslava. Coloquios Espirituales y Sacramentales. México, Universidad Nacional Autónoma de México.

GONZÁLEZ MARTÍNEZ, J. (2007). "El águila del agua: Lepanto visto desde el hampa". En Vega García Luengos, G. y González Cañal, R., Locos, figurones y quijotes en el teatro de los Siglos de Oro. Almagro: Ediciones de la Universidad de Castilla La Mancha, pp. 221-231.

GONZÁLEZ MARTÍNEZ, J. (2012). "La educación del poder a través del teatro: El hijo del águila de Luis Vélez de Guevara". Impossibilia 3: 37-53.

HASSIOTIS, I. K. (2001). "Hacia una re-evaluación de Lepanto". En Bernat Vistarini, A. (ed.), Volver a Cervantes. Actas del IV congreso de la Asociación de Cervantistas, tomo I. Palma de Mallorca, Universitat de les Illes Ballears, pp. 37-45.

HERRERA, F. (1572). Relación de la guerra de Cipre y suceso de la batalla naval de Lepanto. Sevilla, por Alonso Escribano.

HESS, A. C. (1982). "La batalla de Lepanto y su lugar en la historia del Mediterráneo". En Elliott, J. (ed.), Poder y sociedad en la España de los Austrias. Barcelona, Crítica, pp. 90-114.

KIRSCHNER, T. (1998). Técnicas de representación en Lope de Vega. London, Tamesis.

LOFRASSO, A. (1571). El verdadero discurso de la gloriosa victoria que N.S. Dios ha dado al Serenissimo señor Don Juan de Austria contra la armada del Turco en los mares de Lepanto. Barcelona, Pablo Cortey y Pedro Malo. 
MARISCAL HAY, B. (2009). "La batalla naval de Lepanto en el teatro de Fernán González de Eslava”. En Farré J. (ed.), Dramaturgia y espectáculo teatral en la época de los Austrias. Madrid/Frankfurt, Iberoamericana/Vervuert, pp. 371-381.

MATAS CABALLERO, J. (2015). "'La fuerza de las historias representada'. Reflexiones sobre el drama histórico: los reyes de la historia de España en los teatros del Siglo de Oro". En Rouane Soupault, I. y Meunier, P. (eds.), Tiempo e historia en el teatro del Siglo de Oro. Aix-en-Provence, Presses universitaires de Provence, pp. 58-101.

REDONDO, A. (2001). "Sevilla, centro de relaciones de sucesos en torno a 1600: fiebre noticiera y narrativa". En Ruiz Pérez, P. y Wagner, K. (eds.), La cultura en Andalucía. Vida, memoria y escritura en torno a 1600. Estepa, Ayuntamiento de Estepa, pp. 143-184.

REDONDO, A. (2003). "El mundo turco a través de las relaciones de sucesos de finales del s. XVI y de las primeras décadas del s. XVII: la percepción de la alteridad y su puesta en obra narrativa". En Paba, T. y Andrés, G. (eds.), Encuentro de civilizaciones (1500-1750). Informar, narrar, celebrar. Alcalá, Servicio de Publicaciones de la Universidad de Alcalá, pp. 235-255.

RIVERO, M. (2008). La batalla de Lepanto. Cruzada, Guerra santa e identidad confesional. Madrid, Sílex.

SAMBRIAN, O. A. (2011). "In hoc signo vinces: representación y escenificación de las cruzadas en el teatro de Lope de Vega". En Sáez Raposo, F. (ed.), Espacios de representación y espacios representados en el teatro áureo español. Bellaterra, Universitat Autònoma de Barcelona, pp. 149-166.

SAMBRIAN, O. A. (2017). "Imágenes del triunfo de Carlos Quinto en el teatro del Siglo de Oro". Memoria y civilización 20: 11-26.

VEGA, G. (2009). Diccionario Filológico de Literatura Española (siglos XVI$X V I I)$. Madrid, Castalia.

VEGA, L. de (2007). "La Santa Liga". [Edición de Miguel Renuncio Roba]. Association for Hispanic Classical Theater (Comedias.org). $<\mathrm{http}: / /$ artelope. uv.es/biblioteca/textosAL/AL0863_LaSantaLiga.php>

1571. La copia y traslado de una carta venida a la corte de su magestad a los 23 de noviembre en que se cuenta muy en particular la victoria avida de los turcos en la batalla naval. Medina del Campo.

1613. Verdadera relación conforme a muchas cartas que han venido a esta ciudad de la feliz victoria que tuvo don Antonio de Aragón, hermano del Duque de Gandía y sobrino del Duque de Lerma contra las galeras de Chipre y Rodas en la isla de Sio, a mediados de agosto de este año 13. Con otras presas que han tenido las galeras de Venecia, Florencia y los navios del Conde Mauricio. Sevilla, s. 1. 